\title{
An Institutional Right of Refugee Return
}

This is an uncorrected author's draft of an article published in The European Journal of Philosophy. Please cite the published version, available at https://doi.org/10.1111/ejop.12614.

Andy Lamey

Philosophy, University of California, San Diego, 9500 Gilman Drive, La Jolla, CA 92093-0119, United States.

alamey@ucsd.edu

Calls to recognize a right of return are a recurring feature of refugee crises. Particularly when such crises become long-term, advocates of displaced people insist that they be allowed to return to their country of origin. I argue that this right is best understood as the right of refugees to return, not to a prior territory, but to a prior political status. This status is one that sees not just any state, but a refugee's state of origin, take responsibility for safeguarding their welfare. This entitlement I characterize as an institutional right: a right that presupposes, and is a necessary feature of, a particular institution. The institution of which the right of return is an indispensible part is the international political system that sees authority exercised by sovereign states. The institutional argument for a right of refugee return presupposes two basic factual claims about states: they play a central role in safeguarding rights and they pursue exclusionary policies of border control. Importantly, the institutional view presupposes only that states do perform both functions, not that they are justified in doing so. On a purely normative level, the institutional account assumes little more than the moral equality of human beings.

\section{Introduction}

Calls to recognize a right of return are a familiar feature of refugee crises. Particularly when such crises become long-term, advocates of displaced people insist that they should be allowed to return to the country from which they originated. I argue that this right is best understood as the right of refugees to return, not to a prior place, but to a prior political status. This status is one that sees not just any state, but a refugee's state of origin, take responsibility for safeguarding their welfare. This entitlement I characterize as an institutional right: a right that presupposes, and is a necessary feature of, a particular institution. The institution of which the right of return is an 
indispensible part is the international political system that sees authority exercised by sovereign states.

The notion that citizens should be able to return to their country of origin is of course widely accepted. As we will see however a right of refugee return is possessed by a different group of people than the right of civic return. The right of refugee return also remains in effect when a refugee's state of origin ceases to exist. For both these reasons, refugee return and civic return are best viewed as different rights. A theoretical advantage of the institutional account of the right of refugee return (hereinafter, the right of return), is that it relies on parsimonious premises. The institutional argument for a right of return presupposes two basic factual claims about states: they play a central role in safeguarding rights and they pursue exclusionary policies of border control. Importantly, the institutional view presupposes only that states do perform both functions, not that they are justified in doing so. On a purely normative level, the institutional account assumes little more than the moral equality of human beings.

\section{Why an Institutional Right of Return?}

A central motivation for offering a new account of the right of return is to address a situation of devastating loss that routinely befalls large numbers of people, but which receives little philosophical attention. This is the situation of being born stateless. ${ }^{1}$

Refugee crises all too often are multigenerational. The most well-known case is that of the Palestinians, but they are hardly alone. ${ }^{2}$ Members of the Sahrawi people, for example, were displaced from Western Sahara in 1975 following military occupation by Morocco, and have occupied remote desert camps in Algeria ever since. Long exile was also the experience of the so- 
called stranded Pakistanis, speakers of Urdu who were loyal to Pakistan when East Pakistan seceded and became Bangladesh in 1971, after which both Pakistan and Bangladesh denied them citizenship for decades, until Bangladeshi finally accepted them in 2008. It is tragic scenarios such as these, in which human beings pass refugee status on to their children, that generate calls to recognize a right of return. ${ }^{3}$ An overdue task of political philosophy is to outline a version of that right that extends to natal refugees. Call this requirement—fundamental and all-important—-the inclusive condition.

A second motivation for an institutional right of return is to avoid the drawbacks that come with grounding such a right in a prior or more fundamental right to reside in or occupy a particular geographic territory, which has recently received much philosophical attention (Moore, 2015; Stilz, 2017; Tadros, 2017; Halwani, 2008). ${ }^{4}$ An increasingly popular view now characterizes the right of return as a right grounded in a normatively significant relationship that human beings have with the places they inhabit. Proponents of the right to reside in or occupy a particular territory, or territorialists for short, thus frequently argue that the right of refugee return must be a right to return to the geographic place from which they were forcibly displaced. Territorial conceptions of refugee return however cannot justify a right of return for natal refugees, who may have never seen the territory from which their parents or grandparents were expelled. Hence the second condition of a right of return (one that I argue for rather than assume), that it not be grounded in a prior right to reside or occupy a particular territory, or the non-territorial condition for short.

These motivations generate a third requirement that, while not a motivation per se, remains a condition the theory must meet. It is that the 
institutional right of return have applicability to situations of state upheaval. The crises that produce refugees can see their state of origin undergo major transformations, ranging from losing territory through secession to entire states disappearing and being replaced by one or more successors, as the Soviet Union was replaced by Russia and other states. According to the institutional account, both successor and seceded states inherit from predecessor or pre-secession states the duty to uphold a right of return. Of course, one reason states such as Russia are designated successors to previous states is that they occupy common territory. But while territorial continuity features here as a principle of designating successor states, territorial rights do not. We can call this third condition, that of being applicable to situations of state upheaval, the upheaval condition.

My goal is to outline a theory that meets these three conditions. In addition I hope to show that an institutional conception of the right of return is compatible with a range of views regarding the ethics of open borders and theories of justice more broadly. Indeed, because the present account does not challenge the core case for territorial rights but only its rationale for a right of return, the institutional right of return can in principle be embraced even by territorialists.

\section{An Institutional Right of Return}

The right of refugee return is best viewed as an aspect of the global state system that is needed to address the specific vulnerability of refugees, which is statelessness. On this approach the right of return is grounded not in our relationship to something as natural as place but our relationship with something as clearly the result of human artifice as the international state system. On this view return is properly understood as an institutional right. 
Institutional rights are rights that presuppose the existence of, and are meant to operate within, a particular institution. ${ }^{5}$ They can be shaped by, but are nevertheless distinct from, background rights, which presuppose no particular institutions and pertain to society, humanity or even sentient beings. An example of a background right is the right to bodily autonomy. As a moral idea it does not depend on any human creation or institution. General moral commitments of this kind often guide the design of political institutions. Were we to encounter a state that had no legislation enshrining a right to a fair trial, for example, we would think that it was missing a crucial institutional right, one that protected people from being arbitrarily imprisoned. And while the institutional right to a fair trail presupposes the more purely moral background right to bodily autonomy, the two concepts are obviously not synonymous, as the institutional right to a fair trial is meant to guide the functioning of a particular institution, the legal system.

Legal rights are a form of institutional rights, but institutional rights need not be legal. Ronald Dworkin gives the example of a right of a player at a chess tournament to receive a point for checkmating an opponent (Dworkin, 1978, p. 101). The institution in question is the game of chess. Unlike the legal system, rights that guide the functioning of chess are not directly shaped by background rights. We do not think for example that the judges at a chess tournament should award the prize purse to a particular player simply because she was poor. The institutional rights of chess are broadly autonomous from considerations of general morality, in the sense that no one thinks the rules of chess are generated simply by appeal to background rights. A right of return is best thought of as a right that applies to the institution of the modern state system. The birth of the state as we know it is generally 
traced back to the late middle ages, and the Westphalian state system is often said to reach a turning point with the treaty of Westphalia in $1648 .^{6}$ This institution requires institutional rights just as much if not more so than any legal system, let alone a game such as chess. And as in the legal system but unlike chess, background moral rights necessarily guide our thinking about what institutional rights should apply to the global system of state sovereignty.

If state sovereignty is the institution, what is the consideration of general political morality that backgrounds the institutional right of return? It is the entitlement of human beings to equal political consideration and respect. Such an entitlement is widely endorsed in contemporary political philosophy. John Rawls's commitment to moral equality for example is evident in his conception of members of society as "self-originating sources of valid claims ... regarded as free and equal" (Rawls 1985, p. 242-44). Utilitarians disagree with Rawls over what principles of justice the moral equality of persons entails, but they share his commitment to impartial moral concern. In addition to liberalism and utilitarianism, doctrines as diverse as libertarianism and communism are also "egalitarian" in the relevant sense. What these and other theories of justice share is not a commitment to economic equality but rather a more abstract commitment to equal moral consideration (Dworkin, 1983). As Will Kymlicka sums it up, this is the idea that "the interests of each member of the community matter, and matter equally" (Kymlicka, 2002, p. 4).

I take it for granted that human beings do not lose their entitlement to equal concern and respect when they become refugees. If refugees were not entitled to such concern it is not clear how any principles of justice could apply to them or on what basis violations of their rights could be protested. In 
this way my account assumes that all human beings, at a minimum, are worthy of equal consideration. ${ }^{7}$ This is not to say that there can be no just distinction at the level of a particular state's laws regarding citizens and noncitizens. It is rather that the commitment to moral equality entails that everyone, refugees included, have interests that matter equally from the point of view of justice.

If equal moral concern and respect is the main normative premise of an institutional right of return, such a right also relies on factual assumptions. One is that in the modern world, states are expected to protect moral equality by upholding certain responsibilities in their interactions with human beings. States are for example expected to respect the rights of everyone on earth: they cannot actively violate rights, as by for example commissioning an assassination, regardless of where someone is located or whether the victim is a citizen. When it comes to individuals subject to their jurisdiction, however, states are normally thought to have additional responsibilities that go beyond respecting rights and require actively protecting and fulfilling them. ${ }^{8}$ Protection requires police, courts and other legal tools designed to prevent rights violations by third parties, while fulfilment sees a state directly secure the object of a right, as when it provides health and welfare services to its populace. To be a citizen of a state is to be a member of a welfare community for which the state is expected to take special responsibility.

Refugees are in a sense the human excess of the international state system. On the one hand, their country of origin either cannot or will not protect and fulfil their rights-and in some cases actively disrespects them. On the other hand, under the international state system, no other state is automatically compelled to grant them social membership. A central feature of state 
sovereignty rather is the ability to determine who is allowed to become a member of a state's welfare community. ${ }^{9}$ Whether they are justified in doing so or not, contemporary states jealously guard their memberships by restricting immigration. Hence the all too familiar phenomenon of refugees left to languish in camps for years, experiencing long periods in which they can exercise few of the prerogatives of citizenship. In short, if refugees are driven to leave their state of origin because it does not properly attend to their rights, other states also play a causal role in them becoming stateless by implementing restrictive entry policies.

The absence of state concern for one's basic rights is not a small loss. To be sure, the state is not the only institution that concerns itself with rights: international entities such as the United Nations and Non-government Organizations (NGOs) also play a role in basic rights enforcement. But the state today is the primary guardian of rights. There simply is no equivalent entity with the same power to determine whose rights will be upheld or disregarded. This is why refugees can undergo a significant loss in well-being even when they are displaced from states that do not safeguard all of their subjects' rights. Even residents of an illiberal state can pursue a vocation, participate in a religious or cultural community and provide a safe and stable home to their children. While it is not axiomatic that these freedoms will necessarily be lost upon becoming a refugee, this is hardly a remote possibility either. In the modern world being recognized as a subject of a state is a necessary condition of being able to exercise one's rights.

So far as residents of refugee camps are concerned, they can take for granted neither that their state of origin nor the state of exile will recognize them as members of their respective welfare communities. The predictable 
result, even apart from the obvious rights violation that comes with being physically confined to a camp, is that refugee camps exhibit high levels of disease, malnutrition and sexual assault (Connolly et al., 2004; Hynes \& Cardozo, 2000). A basic function of a right of return therefore is to restore refugees to the political status they lost upon becoming refugees, which is the status of someone accepted as a member of a welfare community whose rights are the responsibility of a state to uphold.

\section{Why Return?}

These then are the moral and political bases of the institutional right of return. Human beings are entitled to equal consideration and respect. States play a central role in securing rights. Because a refugee's state of origin does not adequately concern itself with her rights and other states deny her membership, she experiences the extreme vulnerability of statelessness. Yet someone might agree with all of this and still ask why the institutional right refugees are entitled to should be a right of return. Refugees for example could become citizens of their country of exile. So perhaps Afghan refugees in Iranian camps should have a right to become Iranians. Alternatively, refugees might have a right to be resettled in a state other than the state of origin or exile. Why institutionalize a right of return as opposed to these or some other option?

My account is not meant to suggest that refugees never have outcome rights other than return. But if they do, they are necessarily accompanied by a right of return, for four reasons. The first concerns the especially strong interest refugees themselves commonly have in return. Second, a right of return identifies a particular state tasked with admitting refugees, making it more efficient than alternative solutions that do not single-out a particular 
state as bearing responsibility for protecting or fulfilling refugees' rights.

Third, a right of return avoids perverse incentives that can motivate states not to admit refugees or even to create refugees in the first place. Fourth and finally, the right of return is a necessary aspect of a global order in which immigration control, whether or not it is justified, it is a defining feature of international politics.

Refugees have a strong interest in returning to their state of origin because it is the outcome with the greatest likelihood of seeing their previous status most fully restored. In returning to their state of origin refugees are more likely to re-establish the patterns of life that existed prior to exile. This is especially true in cases in which an entire population does not migrate, and most members of a refugee's social network remain in the country of origin.

Even when a large population is forced into exile, however, a refugee's identity can experience unwanted change. This is because what state an individual resides in influences his or her political identity. Consider the cultural affinities between Canadians and Americans. Despite the obvious similarities, being Canadian is a separate identity. As Margaret Moore observes, "Canadians do not have a culture sharply distinct from Americans ... Nevertheless, there is a quite distinct political identity in Canada, with distinct political aspirations" (Moore, 2015, p. 80). The existence of Canadian and other national identities is maintained to a significant degree by the existence of particular states. Given this, being forced to leave the state with which one identifies will make it more difficult to maintain that identity even when the county of exile is culturally familiar. Whether or not every last refugee has a strong desire to maintain their national identity, the ability to maintain such an identity is a reasonable entitlement of justice. Return, unlike 
local integration or resettlement, allows human beings to interact with and be part of the state-defined group with which they most often politically identify.

Of course many refugees do not end up in countries that are culturally familiar. It is not at all uncommon for countries that produce refugees to be located in neighbour states with different languages and cultures. Similarly, resettlement often sees refugees from the developing world brought to a developed state with an unfamiliar language and culture. While it is conceivable that a refugee might be displaced or resettled in a culturally familiar society, exile in an alien culture is a routine occurrence. In cases in which the country of exile is culturally foreign, refugees will have a further reason to desire return. But even when the country of origin is culturally familiar, a right of return protects refugees' interest in secure membership in their pre-expulsion national identity, and their interest in passing that identity on to their children.

The interests of refugees themselves provide the central moral justification for the right of return. As an institutional right, however, the right of return must also function efficiently within the international state system. Part of what makes the right of return efficient in this context—-the second reason why such a right is necessary-is that it clearly identifies the society of expulsion as having a duty to re-admit refugees. This is significant for two different reasons.

The first is theoretical. A prominent version of rights theory holds that rights necessarily generate duties of enforcement that are borne by particular actors or entities (Kagan, 1998, pp. 172-5; Shue, 1996, p. 39). As Onora O'Neill puts it, "[unless] obligation-bearers are identifiable by right-holders, claims to have rights amount only to rhetoric: nothing can be claimed, waived or 
enforced if it is indeterminate where the claim should be lodged, for whom it may be waived or on whom it could be enforced" (O'Neill, 1996, p. 129.) The present account is agnostic on whether this is in fact a conceptual requirement of moral rights, as $\mathrm{O}^{\prime} \mathrm{Neill}$ and others maintain. ${ }^{10}$ Given the nature of institutional rights, however, it seems reasonable to require that some particular state be identified as the entity tasked with the duty of protecting or fulfilling an institutional right. ${ }^{11}$ If we think of the alternative right to resettlement abroad, for example, it is not immediately clear which particular state would be the bearer of such duties. Thus there can be no enforceable right of resettlement in a world of discretionary border control, according to this understanding of institutional rights.

The further reason why it is significant that return immediately identifies a duty-bearer is practical. As noted, even if a refugee has a right to resettlement, this still leaves open which country in particular is obliged to accept her. In terms of any right actually being exercised, it makes a difference whether the duty of enforcement is automatically assigned somewhere, or if it is instead a matter to be negotiated, and so potentially delayed or evaded. A right of return entails that the state of origin has a non-negotiable responsibility to extend the prerogatives of membership to refugees. And while refugeeproducing states are sometimes reluctant to admit refugees in the aftermath of displacement, it is also the case that the majority of refugee camps do eventually close and their occupants do return home. Any means of finding a home for refugees requires that refugees and their advocates identify a potential host society. Return identifies the society of origin as the host, immediately designating it as an appropriate target of moral and political suasion by NGOs, the media, international organizations and other states. 
Of course, the same would be true of a right to be integrated into the society of displacement. Unlike resettlement, but like return, a right to local integration would immediately identify a bearer of the duty to admit refugees. But this brings us to the third fundamental reason supporting a right of return. If refugees had a right to local integration instead of return, it would create two perverse incentives that would increase the probability of refugees' rights being violated.

First, powerful regimes that were prejudiced against minorities or other groups would have an incentive to expel them, as once they became refugees they would become the responsibility of the society of displacement. ${ }^{12}$ Such a right would thus potentially achieve the opposite outcome that a right of return is meant to secure: it would incentivize the creation of more, rather than fewer, refugees.

Second, states that did not want to admit refugees as equal citizens would have a strong incentive not to host refugees to begin with. It is a sad reality that refugees are often not welcome. Even wealthy liberal-democratic states implement no-entry policies for refugees, due to a strong desire not to have to assume permanent responsibility for their welfare (Gibney \& Hansen, 2003). The same motive has seen Tanzania, Thailand and other states in the developing world respond to the arrival of large numbers of refugees by denying them entry or undertaking mass expulsions (Lamey, 2011, pp. 98-9). A right on the part of refugees to local integration, especially one unaccompanied by any right of return, would give states that currently at least tolerate refugee camps a new motive to take extreme steps to prevent refugees from ever entering their territory, trapping them in crisis zones and possibly undermining regional stability as well. ${ }^{13}$ 
Finally, the fourth consideration supporting a right of return is that we live in a world of border control. Whether this arrangement is just or unjust is a subject of philosophical controversy (Wellman, 2008; Miller, 2015; Carens, 2013; Heumer, 2010). The institutional account does not seek to settle this debate. It instead notes that, whether or not discretionary border control is justified in ideal terms, at the level of non-ideal reality it is a central contributing factor to statelessness. The fact that we do not live in a world of open borders is a primary reason for the existence of refugees. So long as states have the power to exclude and warehouse unwanted human beings, the conditions that give rise to statelessness will remain in force. It is not just that authorities in Kenya, Iran and other countries that house large number of refugees do not permit them to leave overcrowded camps. Even when they have the money, refugees normally cannot travel to other states, including wealthy liberal democracies, which exclude them through visa requirements and citizenship law (Gibney, 2004; Lamey, 2011).

So long as those conditions remain in effect, so should a solution in the form of a right of return. If the case for open borders is currently controversial, the norm that states should protect and uphold the rights of their subjects is much less so. The right of return derives force from and reinforces this widely accepted norm, which all states currently operationalize to at least some degree. Insofar as the international system of sovereign states with the power to enforce border control makes it possible for states to reject responsibility for the welfare of subjects from other states, the right of return is based on the insistence that states have a non-negotiable responsibility for the welfare of their own subjects, even after they become refugees. This insistence is compatible with the further insistence that border control is itself an injustice. 
All a proponent of open borders is asked to recognize is that border controls do in fact exist, not that they should.

This account of the right of return does not rule out that there can be additional grounds supporting a right of return for particular refugees. A state of origin that is also the cause of a refugee exodus, as occurs most obviously when people are driven into exile by persecution at the hands of their own government, will have an additional reason to recognize a right of return. Return in such instances will be an acknowledgement of wrongdoing and perhaps also partial restitution for the injustice the same state caused by creating refugees in the first place.

This consideration, however, differs from those mentioned above concerning loss of national identity, the need to identify a particular state tasked with protecting and fulfilling refugee rights, avoiding perverse incentives and mitigating the effects of border control. This fifth consideration will not apply to all refugee scenarios. People can become refugees due to injustices committed by states other than their own, as when their state is under foreign occupation. In other instances the causal chain of injustice may be unclear, with the role of the state of origin difficult to determine or distinguish from that of other actors. ${ }^{14} \mathrm{My}$ goal is to outline a right of return that is universally applicable, and which does not require investigating the precise causes of refugee outflows, which can be subjects of controversy. For these reasons, while I recognize that the restitution consideration will have bearing on particular refugee cohorts, it does not play a justificatory role in my account.

This account of the right of return views it as the right to return to the status of a recognized subject of one's state of origin. Such a view stops short 
of characterizing the right of return, by itself, as the right to return to one's former address. Upon regaining their former political status refugees may well be able to appeal to property and other rights that entitle them to return to their original homes. Insofar as they can effectively exercise such rights however they are no longer stateless, and thus have already regained the status the right of return seeks to restore.

\section{Natal Refugees}

These then are the considerations that justify a right of return for firstgeneration refugees. Crucially, the fact that many of these same considerations apply to natal refugees means that subsequent generations of refugees will also have a right of return on the institutional approach, so long as they continue to experience the vulnerability of statelessness.

Statelessness does the same damage to the interests of natal refugees as it does to those of their parents: they too lack a state that recognizes a responsibility to secure their rights. Natal refugees thus have the same interest in escaping statelessness as their parents. Similarly, the same considerations of efficiency that obtain in identifying their parent's country of origin as their rightful home also apply in the case of their children. There is once again an automatically identifiable state that meets the theoretical condition of being an identified obligation-bearer and which on a practical level can be the subject of pro-return suasion and politicking. And the perverse incentives that would accompany a right of local integration for their parents also apply to a right of local integration for natal refugees. The state of exile would again have an incentive to ensure they never became home to natal refugees, either by not permitting camps to begin with or razing them after a second-generation began to appear. For all these familiar reasons 
therefore, so long as subsequent generations remain stateless, they retain a right of return, regardless of how many generations separate them from the original refugee generation.

The institutional right of return holds that descendants of refugees have the right to live in the state their parents fled. In this way the institutional right of return is conceptually distinct from the right of citizens to return to their state of origin. A non-refugee holidaying abroad for example has a civic right to return to their state of origin. The nature of the right to return however is different when the individual in question is a refugee. It is a separate and distinct right, one that is possessed by refugees rather than citizens. One reason is because the special deprivations refugees face means that there can be legitimate grounds to prioritize their return over that of non-refugees. If a state for example could only take in a limited number of returnees, it should take in holders of an institutional right of return before, say, citizens abroad in states in which they hold a second citizenship, where they can access state protection.

A further difference between the institutional right of refugee return and the right of civic return is that the former necessarily extends to natal refugees while the latter does not. Descendants of refugees retain an institutional right of return so long as they remain refugees themselves. Yet the same conditionality requirement that extends the right of return to later generations simultaneously limits who can posses the right.

Some writers on the right of return have suggested that a minimal condition of any plausible account is that it withhold such a right from descendants of refugees who are not themselves refugees. Anna Stilz cites the case of Germans expelled from Poland in the aftermath of World War II (Stilz, 
2019, pp. 78-9). Their grandchildren have been accepted members of German society from the time of their birth, and so surely should not enjoy any refugee-related right of return to Poland. The institutional account clearly denies these descendants of German refugees a right of return to Poland, for the straightforward reason that they were not born into refugeehood. Conversely, in an alternate universe in which people expelled from Poland had lived in refugee camps for generations in Germany, the descendants of the original refugees would inherit a right of right return under the institutional account, as it holds that such a right is passed down through the generations so long as each remains stateless.

A question raised by the institutional account that I can only gesture at here concerns whether a right of return extends to people who were natal refugees but have since by accepted by a state other than the one their ancestors fled. Suppose for example members of the first generation of Sahrawi refugees have children who are born into refugeehood in Algeria, but subsequently attain permanent residency or citizenship in Spain. Should they continue to enjoy a right of return to Western Sahara, even after they have escaped statelessness in this way? And would our answer change if the formerly natal refugees were not the children of first-generation refugees, but much later descendants, such as their great grandchildren?

The institutional account maintains that natal refugees, so long as they remain refugees, possess a right of return, regardless of generation. It also suggests a default expectation that natal refugees will possess a right of return even after being accepted by another state. But it is arguably consistent with this to hold that at some number of generations removed from the original displacement, whether that of great grandchildren or still later, natal refugees 
who are accepted by another country should lose their right of return to their ancestors' state of origin. Possible reasons for adopting such a view include embracing a supersession thesis, according to which, appropriate rectifications of injustice can evolve over time (Waldron, 1992). Or we might determine that after the passage of enough time, maintaining the same national identity as the first-generation of refugees will cease mattering to a significant number of refugees. ${ }^{15}$ I do not have space to assess different possible answers to this question and their different rationales. But even if we adopt the view that at some point natal refugees who regain an operative nationality thereby surrender their right of return, we will still have accepted the central claim of the institutional account: natal refugees retain a right of return so long as they remain stateless, regardless of generation, and regardless of whether their ancestor's state of origin has legally recognized them as subjects.

\section{Limitations of Territorial Return}

This concludes my outline of an institutional right of return as it is possessed by both first-generation and natal refugees. I turn now to documenting the limitations of a territorialist conception of return, which the institutional account is designed to avoid. Margaret Moore is a leading theorist who has worked out an especially detailed account of territorial rights, so her argument for a right of return will serve as a representative example.

The conception of territory Moore works with is political, denoting land over which someone has legal authority and control. According to Moore, a people has right to its territory that is grounded in an individual right of residency and a collective right of occupancy. In order to understand her 
account of return it is necessary to briefly outline the nature of these two background rights.

According to Moore, human beings have an individual right of residency for two reasons. First, the places we inhabit are where we form relationships, projects and ways of life (Moore, 2015, p. 38). A right of residency thus gives us control over a key condition of being able to pursue our central aims, that of being able to stay in the place we inhabit. Second, human beings often make decisions about what projects to pursue on the assumption that they will do so in a particular place, and that locale can influence the nature of their choices. The lives of Inuit hunters, coastal fishers and many other people are shaped by the territories that they inhabit. A right of residency thus also stabilizes our relationships with the places that can influence who we are.

Turning to the collective right of occupancy, it draws force from the fact that territory is important to human beings on more than just an individual level. They also form connections to particular places as part of a group, for whom the land in question can inform their collective identity. That identity can be damaged when the group is forced from their territory or not able to exercise some degree of control over its character and physical appearance (Moore, 2015, 40). This collective interest in control over land generates jurisdictional rights, which are not present in the individual right of simple residency. The collective right of occupancy differs further from individual rights in that it is possessed by peoples, which are collectives that demonstrate a capacity for self-determination, among other necessary conditions. Examples range from the Inuit people of Labrador to the population of the United States. 
On Moore's view, a right of return is not a refugee-specific right. Nor is it synonymous with the right of citizens to return to their country of origin. It rather applies when either an individual right of residency or a collective right of occupancy is violated. A central question this account raises therefore is on what grounds it can generate a right of return for natal refugees, who have never inhabited the territory of expulsion.

Moore wants her account to generate a right of return that is transmissible to at least some natal refugees. Moore qualifies her support for such a transmissible right of return by also endorsing a supersession thesis, according to which settlers in the refugees' territory of origin can, even if their arrival was unjust, come to posses territorial rights of their own, rights which can outweigh refugees' right of return (Waldron, 1992). ${ }^{16}$ The right of return however is detachable from the supersession thesis, so the latter can be left to one side. "These people [in refugee camps] still suffer the effects of the original injustice," Moore writes in endorsing a transmissible right of return, "and for long-term refugees, this limbo can persist into the second generation. For people in this category, the proper remedy is the right of return" (Moore, 2015, p. 147).

Moore here refers to second-generation refugees rather than natal refugees per se, but let us again set this qualification aside. It is hard to see how even a minimally transmissible right of return does in fact follow from Moore's account. Her appeal to such a right appears ad hoc, unmotivated by any commitment to territorial rights.

Moore here presents the right of return as the solution to the problem of people forced to live in refugee camps for long periods. Moore, however, mischaracterizes the precise nature of that problem by claiming that it is the 
problem of refugees not being able to "develop projects and make plans confident of their background [territorial] context" (2015, p. 147). Long-term refugee populations can often be all too confident that their territorial context will continue to be a camp or shantytown. Someone who has survived 20 years in a refugee camp has been able to plan and build relationship to that point, and can continue doing so on the same basis until they have some reason to believe their situation will change.

What multi-generational camp life deprives individuals of in short is not the stability of place Moore's theory emphasizes. The deprivation instead consists in the quality of the life-plans open to them: their options are more restricted than they would be living outside a camp. Moore's account however does not seek to equalize or minimize the differences between the territorially-enabled life plans human beings possess. The Inuit hunter's right to inhabit the Arctic might seem radically limited to someone used to urban life, for example, but territorialism is immune to qualitative judgements of this kind: what is important is that human beings have $a$ place that they securely inhabit. The nature of such places and the lives they make possible can vary as dramatically as do plans of life enabled by the Arctic and the jungle. Multi-generational refugee camps, sadly, can be stable territories in this minimal way. When it comes to natal refugees therefore, it is not clear how Moore's brand of territorialism can generate even the qualified right of return that she endorses.

This pessimistic conclusion is supported by three further considerations. First, even if Moore were correct in her characterization of the central problem of camp life, it would not follow that return was the proper remedy for natal refugees. If anything her account would seem more likely to support a right 
of local integration in the country of exile, given that it is the only place natal refugees have even known. Second, Moore's right of residency is justified in part by the interest human beings have in stable membership in a community. When entire villages and larger communities are driven into refugee camps, an individual right of residency can provide no reason for why any individual member should be released (which is perhaps why she switches her focus to the quality of life a camp enables). Third, refugee communities sometimes inhabit locations geographically distinct from those they fled. In such instances a natal refugee would be "returning" to a territory geographically unlike they one they grew up in-an outcome Moore's view, like most versions of territorialism, does not support, as different landscapes make possible different life-plans.

This then is the central limitation of a territorial conception of return: it cannot ground a right of return for natal refugees without resorting to ad hockery. Because I have challenged only the ability of the theory to generate a right of return for natal refugees and not the case for territorial rights in itself, one possible response to my critique would be for a territorialist to endorse the institutional account, thereby combining the two views. It is helpful however to note a second aspect of the theory in its unmixed version, less to show its defects than to illustrate how it and the institutional account differ in a fundamental manner that may not be apparent at first glace. The institutional account, unlike its territorial counterpart, does not seek to determine the appropriate restitution for all forms of injustice involving displacement.

An attractive feature of theories of territorial rights is their sustained concern with injustices committed against indigenous peoples under 
colonialism. One such injustice was administrative relocation. An example cited by Moore is the relocation of Inuit people in Canada. In 1958 and 1959 two remote Inuit villages in Labrador saw the withdrawl of medical and other services that the residents had come to depend on (Brice-Bennett, 2017; Moore, 2015, p. 41). The decision to relocate was one that the community members had no control over. The towns to which they were relocated were hundreds of miles to the south, a distance sufficient to change their way of life. Where they had once been able to sustain themselves through hunting, they now succumbed, as Moore writes, to "a culture of dependency and dislocation, and social ills" (Moore, 2015, p. 41).

This case has been invoked as a challenge to the present view. "It's hard to see how this [institutional] account has applicability to the case of the Labrador Inuit," one anonymous referee has written, "since they are already in the state. Is this just a case of property rights? To be a plausible account, we need to consider hard cases." ${ }^{\prime 17}$ This objection however only shows that there is a structural difference between territorial and institutional approaches to return that is easy to overlook. Institutionalism outlines a right of return specific to refugees. Internally displaced people do not meet the definition of a refugee because they are not outside their country of origin. On the institutional account therefore the key question to ask of internally displaced people is whether they experience statelessness.

Common aspects of statelessness include not being able to legally obtain work or education, either for oneself or one's children. People without the protection of a state cannot go to the police without fear. Many receive no state welfare and must rely instead on humanitarian aid. These conditions can all obtain even when a stateless person is not confined to a refugee camp. Had 
the Labrador Inuit been formally denied the right to work and welfare and herded into camps, it would have been right, on the institutional account, for NGOs, the media and the Inuit themselves to press for their restoration as rights-bearing subjects under Canadian law. Of course we already accept that governments should not violate the rights of their subjects. But a right of return is a response to the especially severe vulnerability that is experienced by human being whom no state anywhere recognizes as a subject. Internally displaced people who experience statelessness are essentially refugees but for the fact they remain within their state of origin. Given the common experience of statelessness, they too are entitled to an institutional right of return. But for reasons that should now be obvious, this restoration of political status could occur without seeing the internally displaced return to their former places of residence.

The Labrador Inuit experienced a different wrong that the withdrawal of state protection. After relocation they could still legally work, go to school, engage the police or travel within Canada. As such, they fall outside the scope of those whose plight the institutional account of return is meant to address. It hardly follows that no wrong was done to them. As noted above, the purely moral right that backgrounds the institutional right of return is one of equal consideration and respect. The Labrador Inuit were relocated as a result of a process that did not treat them as equals. Rather than ask whether they wanted to relocate, local authorities decided for them. This approach reflected a colonialist mindset. The fundamental moral value that grounds the institutional right of refugee return thus condemns the relocation on intuitively plausible grounds, a failure to respect the Inuit as moral equals. ${ }^{18}$ 
The institutional account also does not deny that the Labrador Inuit were entitled to some form of redress. Historically, the actual redress was an apology and a monument (CBC News, 2009). Perhaps some other form of redress would have been better, including the restoration of services in their old villages. But if they were entitled to a restoration of village services, it was due to rights to minority cultural support, family re-unification, property or other grounds that need not presuppose a need to escape statelessness. The institutional right of refugee return leaves open what if any other rights might be operative here. It does not hold that the right form of redress in every case must involve a return to a geographic place of origin.

For territorialists, because administrative removal cases involve leaving a territory, they must be subject to the same remedy as refugee displacement. Territorialists in this way are hedgehogs: there is one big solution, a right of territorial return, that applies to all cases of displacement whether or not the victims experience statelessness. Institutionalists by contrast are foxes: they accept different solutions to different cases of displacement depending on whether or not they involve statelessness. The Inuit Labrador case is only a "hard case" therefore if one assumes that there can only be one solution to all forms of displacement. This issue itself however is part of what is at issue between territorialist and institutionalist views when the two accounts are taken in their own terms rather than combined. To assume the hedgehog view therefore is to beg the question against institutionalism.

\section{States of Upheaval}

The simplest case of return involves the return of a refugee to their country of origin. I have outlined how the institutional right of return applies to one kind of extension case, that of natal refugees. Refugees however take flight in 
a wide range of scenarios, including those that see their state of origin undergo significant transformation. Given this, let us now consider how the institutional account applies to two kinds of state upheaval: that in which a refugee's state of origin disappears and is replaced by a successor state; and that in which a refugee resides in part of a state that secedes, such that a refugee's original locale or residence is now located outside their former country.

The most significant transformation a refugee's state of origin can undergo is to disappear. During its existence for example the U.S.S.R. produced many refugees. Because these "defectors" were coming from a Warsaw Pact country, they received a warmer reception than most other refugees, as Western states were keen to score a public relations victory against Stalinism (Gibney, 2004, p. 114, p. 177). Soviet Bloc refugees therefore generally did not experience long periods statelessness the way residents of refugee camps do. Nevertheless, for illustrative purposes, let us imagine refugees from the Soviet Union who were stateless at the time of the U.S.S.R.'s collapse. On the institutional account, Russia would have inherited the duty to admit stillstateless Soviet refugees.

Disappearing and being replaced by a successor is not the only way states can be transformed. They can also see part of their territory secede. This was the backdrop to the case of the stranded Pakistanis, also known as Biharis, for whom both Pakistan and Bangladesh refused to take responsibility after the latter seceded. In such cases the institutional account holds that refugees have a right of return to either state. So in the Bihari case, a right of return to either Pakistan or Bangladesh. 
The case for a right of return to Pakistan follows straightforwardly from the account presented above. If after the Bangladesh War of Independence there were former citizens of Pakistan now experiencing statelessnesswhether in Pakistan, Bangladesh or a third country-their transformation into refugees would not see them lose their right to the protection of the government that they formerly enjoyed. In particular, should there be any Pakistani refugees outside Pakistan's borders, this fact would not be grounds for Pakistan to discard them or their children like refuse, writing them off as the responsibility of whatever state happened to house them.

At the same time, however, the institutional understanding of return also generates a duty to recognize a right of return on the part of Bangladesh. Insofar as Pakistan still existed after Bangladesh seceded, Bangladesh was not the successor state to Pakistan. But Bangladesh in this context has something in common with successor states such as Russia, in that Bangladesh laid claim to a portion of Pakistan. Such cases are instances not merely of secession but also of split succession, insofar as one state, here Bangladesh, takes on authority over a portion of a state that otherwise continues to exist. If we were to take the entire civic community of Pakistan as it existed prior to the secession crisis, authority over all of its people and territory is no longer the responsibility of a unitary Pakistani state but is now split between Pakistan and Bangladesh.

The same considerations that justify a right of return in simple cases all apply to states of upheaval involving successor states such as Russia. Refugees again have an interest in returning to their former life as a protected subject of a state; the right again functions efficiently as part of the 
international state system in a manner that avoid perverse incentives; and the potentially devastating effects of border control are again mitigated.

In Bangladesh-style cases involving secession, the rationale of a refugee returning to their previous way of life does not apply with the same force. Someone long resident in what was East Pakistan could "return" to what was formerly West Pakistan, effectively beginning a new chapter in their life as a citizen of Pakistan. Secession cases also do not have quite the same clarity regarding which state in particular is obliged to take in refugees as is true of simple cases: there will now be two or more states automatically obligated to accept return. But otherwise all the same considerations again apply. Central to both upheaval scenarios is that a right of return presents refugees with a path out of statelessness, in a manner that encourages long-term justice and stability in the international order. The case for return again begins from a norm that the majority of states already accept, responsibility for their subjects, rather than from a norm of open borders which, however sound it may be in ideal terms, is widely disputed at the level of non-ideal reality.

What are the criteria by which one state is designated a successor to another, in cases of both unitary and split succession? Historically, a central consideration has been whether a candidate successor state is composed of (part of) the predecessor state's territory, in addition to its people and assets (United Nations, 1978). Given the prominence of territory on this list, one might ask how the institutional account of return can appeal to the notion of a successor state in both Russia- and Bangladesh-style cases given that the institutional view strives to offer a non-territorial conception of return.

The answer here is straightforward. The institutional account does not deny that states are territorial entities. What is seeks to avoid is basing the 
right of return on an appeal to territorial rights. It is therefore no embarrassment to the institutional account if territory figures in the basis of designating a successor state, to which a refugee now has a right of return. For it was already the case when the predecessor state existed that it was defined in part by its territorial location. Given this, the issue of having to designate one or more successor states does not introduce a new role for territory into the theory, let alone a new role for territorial rights.

Designating successor states in upheaval cases requires no appeal to the idea that human beings have a right to inhabit a particular place. Suppose for example that Bangladesh accepted responsibility for all Bihari refugees, but they ended up living somewhere other than their pre-secession residence. These people, just as much as Biharis who "returned" to rump-state Pakistan, would have exercised a right to return to their former status as a subject of a civic community that formerly was a component part of greater Pakistan. They would not have exercised a right to return to their former geographic territory. The institutional account does not rule out that individuals in such circumstances could have other grounds to return to their original homes, such as property restitution or family reunification. But insofar as they were truly accepted as members of either civic society, their statelessness would thereby come to and end. At that point they would attain the standing as permanent residency or citizenship that is a necessary condition of making recourse to property rights or other legal sources of restitution regarding their homes.

In sum, it is possible to regain state protection by being accepted by a state that governs over one's old territory without returning to the old territory itself. This however is not the only reason cases of state upheaval presuppose 
no commitment to territorial rights. Territory can be used as a means of identifying successor and divergent-successor states for reasons unrelated to rights, in particular, for reasons of efficiency.

Historians of the international state system often note that one of the central reasons it achieved global dominance is its greater efficiency that other forms of authority. It is not possible here to document the many confusing and dysfunctional aspects of systems of political authority that differ from the model of a state wielding authority within set borders and only within those borders (Spruyt, 1994, pp. 34-58.) But one reason sovereign states have come to capture every land mass on earth save Antarctica is that they clearly demarcate one ultimate authority.

It was common for Medieval popes, emperors, monarchs, lords and cityleagues to claim authority over the same person or place simultaneously. As historian Hendrik Spruyt has written, "the logic of feudal organization lacked a sovereign, a final source of authority and jurisdiction" (Spruyt, 1994, p. 38). Modern states by contrast exert ultimate jurisdiction within their domains. Domestic political life thus attains greater predictability and stability than it does under non-territorial systems of authority, under which it was often not clear who ultimately held authority. The same is true internationally. Sovereign states have long found it easiest to conduct foreign relations with other sovereign states. Historically this resulted in a "process of mutual empowerment," whereby states reciprocally recognized each other's sovereignty while withholding such recognition from non-states (Spruyt, 1994, p. 179).

If territory is an efficient means of organizing and recognizing political authority to begin with, it is an even more efficient means of identifying 
successor states within a system that is already committed to organizing authority territorially. Periods of state upheaval can see entire geo-political regions descended into chaos. A norm that clearly and unambiguously identifies states that inherit a duty of return is a simple and effective means of ensuring that chaotic periods do not see refugees lose their fundamental right of return, which in the final analysis is a right to return to their former status as a subject of a civic community, not to a particular territory.

Above I argued that the institutional right of return differs from the right of civic return by extending to include natal refugees. Scenarios of state upheaval illustrate a second manner in which the rights of refugee return and civic return differ. By clearly designating states that inherit the responsibility to admit refugees in scenarios or state disappearance, secession and redrawn borders, the institutional account makes substantive claims about which the right of civic return is silent. Historically states have been all too willing to use situations of state upheaval as an excuse to disregard the rights of an unpopular minority. The institutional right of return identifies which particular states have the duty to admit refugees in such scenarios in a way that general affirmations of civic return do not.

The institutional account of return seeks to function as part of the international state system. Yet while that system sees states wield power territorially, this is ultimately an incidental feature of states on the institutional account. We can see this by noting the applicability of an institutional right of return to non-territorial forms of political authority. So imagine a world in which there are no states. Political authority is exercised instead by bands of nomads who range over a vast and diverse landmass, larger even than that over which Ghengis Khan once rode. There is an internal 
structure of authority within each band, such that that some members function as the ultimate arbiter of political matters. Such matters might include the distribution of resources within the band, whether they will go to war with other bands and which members of these other bands will be recognized as rightful sovereigns. In this and other ways, the nomad leaders perform functions currently performed by states. Now imagine a crisis that sees some members of a given band become isolated and forced to live in refugee-like conditions. Perhaps for example there were ways of earning a living, participating in political life or educating their children that were available to them when they rode with the band, but now, abandoned in some wasteland, these goods, like the good of mobility itself, are lost to them.

An institutional right of return is applicable to the imaginary nomadic world. It would hold that refugee-nomads had a right to return to their original band. Or, if the band had split, to either successor band. The rationale for such a right of return would be the same as offered above. They are human beings who have been deprived of a basic level of political protection and recognition that is provided by sovereign entities. The only difference is that the sovereign entities are mobile rather than territorial. It so happens that in our world the political entities that exercise sovereignty are territorial states. But what is essential to the institutional account of refugee return is their sovereignty, not their territoriality.

\section{A Liberal Spirit}

The institutional account of return seeks to extend the right of return to natal refugees, to avoid appeal to territorial rights and to be relevant to situations of state upheaval. The fact that it reaches these conclusions from widely shared normative premises however means that it can in principle also 
be endorsed by a broad range of views, up to and including those that endorse territorial rights. In this way it shares the spirit of Rawlsianism and other liberal philosophies that seek to outline principles of justice that can be embraced by proponents of reasonably diverse religious, moral—and in this case, political—views (Rawls, 1993).

Consider theories that endorse and oppose a state's right to limit immigration. The institutional account recognizes as a matter of fact that states do have this power, but it is silent on whether or not it is justified. This silence means that both proponents and critics of open borders can in principle endorse an institutional right of return. The need for a right of return in a world of open borders is unclear, as refugees could potentially resettle in any state other than their state of origin. Perhaps however even in such a world there would be need for such a right, so long as states retained the power, even if they did not exercise it very often, to turn away needy migrants. The fact that we do not live in such a world, however, is sufficient grounds to endorse an institutional right of return, the need for which can be separated from the question of whether or not immigration control is legitimate at the level of ideal justice.

The same is true of theories that endorse and oppose the legitimacy of the state. So far as the institutional account of a right of return is concerned, the essential point again is that states do in fact play a central role in guaranteeing rights, whether or not they should, and whether or not their own territorial claims are justified. Thus even an anarchist can recognize an institutional right of return as a necessary instrument of non-ideal justice. ${ }^{19}$ The institutional account presumes that human beings warrant equal moral consideration and respect, and that a state-based system of international 
justice is one step closer to justice with a right of refugee return than without. Such judgments can be affirmed even by those who doubt the justice of the state system itself.

Finally, the institutional account is compatible in principle with some form of territorialism. The criticisms of territorialist accounts offered above focused on their implications for refugee return rather than the core concept of territorial rights. There may be no contradiction in the thought that human beings possess territorial rights and one or more institutional rights particular to the institution of state sovereignty. I make no assumption that taking on board an institutional right of return would leave a theory of territorial rights unchanged. But there is no reason in principle why an institutional right of return must necessarily function as an external threat, rather than congenial supplement, to some version of territorial rights.

\section{Conclusion}

"The first loss," Hanna Arendt famously wrote of refugees, "was the loss of their homes, and this meant the loss of the entire social texture into which they were born in which they established for themselves a distinct place in the world" (Arendt, 2004 [1951], p. 372). For decades, passages such as this have been read as characterizing a refugee's most fundamental loss as a loss of a physical place. If the present account is correct, however, there is another way to conceive of refugee's lost "place in the world." It is the sense a member of a nomadic band, for example, would use is saying that her "place" was with the band that had long included her as a member. "Place" in this sense is a political, not a geographic, concept. The institutional account holds that refugees, wherever they may be found, possess the right to return to their 
place in a system in which upholding fundamental rights is the responsibility of states.

This defence of an institutional right of return arrives at a time when scholars of refugee issues devote increasing attention to alternatives to return (Adelman \& Barkan, 2011; Long, 2013). One motivation for exploring such alternatives is that return to the state of origin is often politically impossible. It can however be true that we have a right to do something that political conditions prevent us from doing, and nothing in the institutional account denies that pursuing options other than return will sometimes be necessary (Lamey, 2020). But history suggests that a right of return is no small entitlement. Basic human rights have been called "the morality of the depths. They specify the line beneath which no one is allowed to sink" (Shue, 1996, p. 18.) The right of return is ultimately a morality of the lower depths. It seeks to ensure that when human beings do fall below the line, or, worse, are born beneath it, they do not sink below the point of no return. ${ }^{20}$

\section{References}

Adelman, H. and Elazar Barkan (2011). No return, no refuge: Rites and rights in minority repatriation. New York: Columbia University Press.

Arendt, H. (2004 [1951]). The origins of totalitarianism. New York: Shocken.

Brice-Bennett, C. (2017). Dispossessed: The eviction of the Inuit from Hebron, Labrador. Montreal: Isberg.

Carens, J. (2013). The ethics of immigration. Oxford: Oxford University Press.

CBC News. (2009, July 24). Relocated Labrador Inuit to get apology monument. CBC.ca. https:// www.cbc.ca/news/canada/newfoundlandlabrador/relocated-labrador-inuit-to-get-apology-monument-1.852737\#.

Chatty, D. (2013). Refugees in the Middle East: Identity politics among Sahrawi, Palestinian and Afghan youth. In M. Hashemi \& M. Sánchez (Eds.), Children in crisis: Ethnographic studies in international contexts (pp. 4260). New York: Routledge. 
Cochrane, A. (2018). Sentientist politics: A theory of global inter-species justice. Oxford: Oxford University Press.

Connolly, M., Gayer, M., Ryan, M. J., Salama, P., Spiegel, P. and Heymann, D. L. (2004). Communicable diseases in complex emergencies: Impact and challenges. The Lancet, 364, 1974- 1983.

Dworkin, R. (1978). Taking rights seriously. Cambridge, MA.: Harvard University Press.

Dworkin, R. (1983). Comment on Narveson: In defense of equality. Social Philosophy and Policy, 1, 24- 40.

Gibney, M. (2004). The ethics and politics of asylum. Cambridge: Cambridge University Press.

Gibney, M. \& Hansen, R. (2003). Deportation and the liberal state: The forcible return of asylum seekers and unlawful migrants in Canada, Germany and the United Kingdom. UNHCR Evaluation and Policy Analysis Unit.

Halwani, R. (2008). The right of return. In R. Halwani \& T. Kapitan (Eds.), The Israeli-Palestinian Conflict: Philosophical essays on self-determination, terrorism and the one-state solution (pp. 72-131). London: Palgrave Macmillan.

Heumer, M. (2010). Is there a right to immigrate?. Social Theory and Practice, 36, 429- 61.

Hynes, M. \& Cardozo B. L. (2000). Observations from the CDC: Sexual violence against refugee women. Journal of Women's Health $\mathcal{E}$ Gender-based Medicine, 9, 819- 823.

Kagan, S. (1998). Normative Ethics. Boulder, CO: Westview Press.

Koch, I. (2012). Dichotomies, trichotomies, or waves of duties?. Human Rights Law Review 12, 81- 103.

Krasner, S. (1999). Sovereignty: Organized hypocrisy. Princeton: Princeton University Press.

Kuosmanen, J. (2013). Perfecting imperfect duties: The institutionalisation of a universal right to asylum. The Journal of Political Philosophy, 21, 24- 43.

Kymlicka, W. (2002). Contemporary political philosophy: An introduction (2nd ed.). Oxford: Oxford University Press.

Lamey, A. (2011). Frontier justice: The global refugee crisis and what to do about it. Toronto: Doubleday Canada.

Lamey, A. (2020). Can there be a right of return?" The Journal of Refugee Studies, $1-12$.

Long, K. (2013). The point of no return. Oxford: Oxford University Press. 
Miller, D. (2015). Is there a human right to immigrate?. In S. Fine \& L Ypi (Eds.), Migration in political theory: The ethics of movement and membership (pp. 11- 31). Oxford: Oxford University Press.

Moore, M. (2015). A political theory of territory. Oxford: Oxford University Press.

Norwegian Support Community for Western Sahara (2008, February 6). Belgian ex-senator runs in sand dunes for Sahrawi peoples' rights. http:/ / www.vest-sahara.no/a104x793

O'Neill, O. (1996). Towards justice and virtue. Cambridge, Cambridge University Press.

Philpott, D. (2001). Revolutions in sovereignty: How ideas shaped modern international relations. Princeton: Princeton University Press.

Rawls, J. (1985). Justice as fairness: Political not metaphysical. Philosophy \& Public Affairs, 14, 223- 51.

Rawls, J. (1993). Political Liberalism. New York: Columbia University Press.

Sen, S. (2000). Stateless refugees and the right to return: The Bihari refugees of South Asia - part 2. International Journal of Refugee Law, 12, 41- 70.

Shue, H. (1996). Basic rights: Subsistence, affluence and U.S. foreign policy (2nd Ed.). Princeton, Princeton University Press.

Simmons, A. (2016). Boundaries of authority. Oxford: Oxford University Press.

Spruyt, H. (1994). The sovereign state and its competitors: An analysis of systems change. Princeton: Princeton University Press.

Stilz, A. (2017). Settlement, expulsion, and return. Politics, Philosophy $\mathcal{E}$ Economics, 16, 351- 374.

Stilz, A. (2019). Territorial sovereignty: A philosophical exploration. Oxford: Oxford University Press.

Tadros, V. (2017). The persistence of the right of return. Politics, Philosophy $\mathcal{E}$ Economics, 16, 375- 99.

United Nations (1978). Vienna Convention on Succession of States in Respect of Treaties.

Waldron, J. (1992). Superseding historical injustice. Ethics, 103, 4- 28.

Wellman, C. (2015). Immigration and freedom of association. Ethics, 119, 10941.

Ypi, L. (2013a). Territorial rights and exclusion. Philosophy Compass, 8, 241- 253. 
Ypi, L. (2013b). What's wrong with colonialism. Philosophy \& Public Affairs, 41, 158- 191.

${ }^{1}$ The form of statelessness I have in mind is de facto, as when refugees cannot take for granted that the law will protect their rights, even through they have not been formally denationalized. Statelessness can also be de jure, as when refugees, in addition to experiencing this same form of vulnerability, are also formally stripped of their citizenship.

${ }^{2}$ Beyond return, the Palestinian case involves the issue of creating a Palestinian state, which I leave aside.

${ }^{3}$ For affirmations of the right of return of Sahrawi and Pakistani refugees see The Norwegian Support Committee for Western Sahara (2008) and Sen (2000).

${ }^{4}$ For a helpful taxonomy of theories of territorial rights see Ypi (2013a).

${ }^{5}$ My account of institutional rights follows Dworkin (see Dworkin, 1978, pp. 101-5).

${ }^{6}$ For the rise of the international state system see Spruyt (1994) and Philpott (2001).

${ }^{7}$ As a minimum because proponents of equal moral consideration can differ on whether animals are also subjects of justice. For the view that they are see Cochrane (2018).

${ }^{8}$ For the historical development of states' tripartite duty regarding rights see Koch (2012).

${ }^{9}$ For the diverse components that constitute sovereignty see Krasner (1999).

${ }^{10}$ For criticism of O'Neill's view see Kuosmanen (2013).

${ }^{11}$ The international state system can give rise to institutional rights that are secured, not through protection or fulfilment, but the third option mentioned above, respect. Although I do not have space to explore it here, I am drawn to the possibility that the right of non-refoulement, or the right of refugees not to be returned to states where they have a well-founded fear of persecution, is an institutional right of this kind. If non-refoulement is an institutional right that is upheld through respect, however, then it will not require a particular 
obligation-bearer to be identified among states: rather all states will be required to refrain from returning refugees to danger. Given the possibility of institutional rights with this structure, I do not go so far as to say all institutional rights within the state system must have duties of enforcement that are borne by particular states: only institutional rights that are secured through protection and fulfilment must be particularized in this way.

${ }^{12}$ This is a major weakness of Adelman and Barkan's (2011) argument that the right of return should be replaced with a purely pragmatic approach to refugee settlement, one that would decide on return, local integration or resettlement on a case by case basis (see Adelman \& Barkan, 2011, pp. 220-36). For criticism see Lamey (2020).

${ }^{13}$ Some readers might worry, as an anonymous referee does, that "to prioritize the right of return is to create perverse incentives for states of refuge to delay or deny access to their nationality to refugees." Given this, one might think what refugees really deserve is a right to an operative nationality, which can be regained through return, local integration or resettlement. In response, I note that my account does not entail that return is always the best outcome to seek in practice. We can have rights that it is sometimes not possible to act on, and there will be cases in which local integration or resettlement are more prudent and realistic goal. Regarding a right to an operative nationality, it faces the same problem as a right of resettlement, discussed above: no state in particular would bear a non-negotiable responsibility for fulfilling it (bestowing nationality on someone is here seen as a right that cannot be upheld merely through respect, and instead requires fulfilment). Also, insofar as a right to an operative nationality made a state of refuge potentially rather than automatically the bearer of a permanent duty to uphold the rights of refugees, it risks the perverse incentive problem outlined above. In the Tanzanian case, for example, Tanzania denied entry to approximately 20,000 refugees seeking entry from Burundi in 1995. A right to an operative nationality that makes states of refuge potential bearers of permanent duties to any refugees who cross their borders risks exacerbating the international trend of no-entry policies, which is already a serious problem. This possibility of this occurring might be reduced by affirming a refugee right to local integration in addition to, rather than instead of, a right of return. I do not have 
space to explore this possibility here. But even if this view proves correct, it still suggests the need for a right of return.

${ }^{14}$ Gibney (2004, p. 7) notes that some definitions of refugee include people forced to flee deadly viruses such as Ebola. My account leaves open the possibility of refugees needing a right to return to a state from which they were displaced by a virus, which was able to spread despite the state in question acting justly (e.g. the state lacked adequate resources, or a wealthy outside state would not share a cheap vaccine).

${ }^{15}$ A hypothesis that Chatty (2013) suggests is at odds with the experience of Sahrawi and Palestinian refugees to date.

${ }^{16}$ For criticism of Waldron's supersession thesis see Simmons (2016, pp. 15386).

${ }^{17}$ According to the referee, "I was rather attracted to the territorialist position but I think the right of residency is individualist in the sense that it is simply a right to remain in the place where one resides, if one resides there not unjustly." For a theory of territory similar to the one the referee affirms see Stilz (2017).

${ }^{18}$ For a characterization of colonialism as a failure to respect moral equality see Ypi $(2013 b)$.

${ }^{19}$ Refugees are by definition outside their state of origin. In a stateless world there would therefore be no refugees and so no need for a specific right of refugee return. Human beings could still experience rights violations, but the specific vulnerability of statelessness as it occurs in the modern world, which presupposes the existence of states with the power to exclude, would not occur.

${ }^{20}$ I am grateful to referees at three journals for their comments, but above all to a referee at this journal for some especially constructive suggestions. 